\title{
Encouraging and Supporting Minority Entrepreneurship for Long-Term Success
}

\author{
Ozlem Ogutveren Gonul (Drexel University)
}

KEYWORDS: Entrepreneurship, Startups.

Entrepreneurs and their ventures have a huge impact on the social, political and most of all economic well-being (Light \& Rosenstein, 1995) of communities, cities and countries around the world, but launching a new business has its own challenges and risks. Young entrepreneurs have courage and passion but usually lack know-how, important skills, business knowledge and experience, necessary networks, a good team and funding. Due to limited resources, more than half of new businesses in the US fail within the first five years of operation. (Badal, 2014).

The risks are even greater for minority-owned businesses (MOBs). While they are an indispensable component of the U.S. economy (Sonfield, 2001) MOBs face more challenges and tougher challenges than nonminority businesses. According to the Quick Facts United States, published by US Census Bureau, minorities accounted for $25 \%$ of the US population in of July 2017 (other studies estimate that number at around $35 \%$ ). There is a significant demographical change in the US. However, minorities do not account for their proportional part in the US economy as a result of lack of access to resources (Greenhalgh \& Lowry, 2011).

This paper reviews the current state of minority entrepreneurship in the US; explains the problems and challenges faced by minority entrepreneurs; discusses various support mechanisms provided for minority entrepreneurs and gives examples of successful examples; and offers suggestions for supporting them further.

\section{State of Minority Entrepreneurship in the US ${ }^{1}$}

The Federal definition of a minority-owned business is that at least $51 \%$ of the firm is directly and unconditionally owned by one or more members of a minority group, or more recently called a "socially disadvantaged" group (Sonfield, 2001). MOBs have not been extensively researched but they have high potential to grow and contribute to the overall economy and employment. We need to understand their problems and challenges in order to develop new approaches that will help them flourish in the business world.

The MOBs gained increasing attention from scholars, public and private organizations after 1980s. Between 1987 and 1997 the US economy experienced strong economic growth, high rates of employment, low inflation and unprecedented growth in high-technologybased businesses. During that same period the number of MOBs increased by $150 \%$, from $1,213,750$ to 3,039,033 (Didia, 2008, pp. 195-196). The Survey of Business Owners (SBO) in US (2012) shows further rise in numbers of MOBs in recent years (Table 1).

Table 1: Number and Percentage of MOB and Non-Minority businesses in the U.S. in 2012

\begin{tabular}{|l|l|l|}
\hline & $\begin{array}{l}\text { Number of } \\
\text { Businesses }\end{array}$ & $\begin{array}{l}\text { \% of US } \\
\text { Businesses }\end{array}$ \\
\hline Black/African American & $2,584,403$ & 9.5 \\
\hline $\begin{array}{l}\text { American Indian and Alaska } \\
\text { Native }\end{array}$ & 272,919 & 1.0 \\
\hline Asian & $1,917,902$ & 7.1 \\
\hline $\begin{array}{l}\text { Native Hawaiian/Pacific } \\
\text { Islander }\end{array}$ & 54,749 & 0.2 \\
\hline Hispanic & $3,305,873$ & 12.2 \\
\hline Minority & $7,952,386$ & 29.3 \\
\hline Non-Hispanic White & $19,278,260$ & 70.9 \\
\hline
\end{tabular}

Table adapted from: Minority Business Ownership: Data from the 2012 Survey of Business Owners, Issue Brief Number 12, September 2016, US Small Business Administration, Office of Advocacy. Note: Percentages may not sum to $100 \%$ due to those identifying as two or more races, or an "other" race.

While the MOB numbers increased throughout the years, a closer look at the data is more discouraging:

- In 2012, only $11.4 \%$ of the MOBs had paid employees, whereas $88.6 \%$ were non-employer firms.Among firms with less than 20 employees $45 \%$ are MOBs. The figures decrease as the firm size increases: MOBs account for $30 \%$ of 
the companies with employees $20-99,14 \%$ of the companies with employees 100-499 and only $12 \%$ of the companies with 500 and more employees.

- Among the industries MOBs operate, the highest average number of employees per firm is in employment services, warehousing and storage. Gas stations are the most likely to have paid employees $(88.3 \%$ of minority-owned gas stations have paid employees, compared to $11.4 \%$ of all minority-owned firms). These statistics show that most of the MOBs are not able to contribute to the economy through employment and/or skilled labor.

- While MOBs account for $29 \%$ of US companies, among the high-patenting industries the percentage drops to 13 (data is compiled from Survey of Business Owner Facts: Minorityowned businesses in the U.S. by U.S. Small Business Administration https://www.sba.gov/sites/default/files/SBO_Fac ts_MOB.pdf).

Although the number of MOBs increased, researchers have studied important questions about the success and growth of these firms. Did the MOBs get their proportionate share of growth of earnings and profits, especially in the economic growth periods? Do MOBs in all industries grow as well as their non-minority counterparts?

Researchers have seen a significant lag for MOBs in terms of revenues generated and employment, which are important indicators for success and growth. For example, in the growth period of 1987-1997, "MOB revenues increased by $660 \%$, from $\$ 77,840$ million to $\$ 591,259$ million. In the same period, revenues of all US firms increased by $830 \%$, from $\$ 1,994,808$ million to $\$ 18,553,243$ million. Accordingly, MOBs account for only $3.2 \%$ of all revenues generated by businesses in US during this period." (Didia, 2008, p. 196). During the same period, in most of the MOBs' industry niches, such as food stores, the number of firms and paid employment showed no growth (Bates, Jackson III \& Johnson Jr., 2007).

Other research on minority entrepreneurship finds that representation of minorities in business ownership, growth and success are low due in part to some major barriers of entry into the field. It is also clear that MOBs face more challenges and problems, and to a greater extent, than the non-minority businesses (Bates, 2011; Adkins \& Samaras, 2013; Barr, 2015; Ogbolu, 2015).

\section{Challenges Minority Entrepreneurs Face}

How do minority businesses take root and grow, and what challenges and problems do they face? Several theories shed some light on this. Ethnic niche approach, branching from the population ecology theory, refers to entrepreneurial occupation as a foundation for an ethnic enclave economy of a specific minority group (Boyd, 1996; Smith-Hunter, 2003). This means that these businesses employ and cater to the same specific ethnic group. These ethnic entrepreneurs may have a special skill or cultural know-how to fulfill the needs of the specific ethnic group (Smith-Hunter, 2003). Examples of this type of businesses include ethnic clothing, ethnic food restaurants and markets, hair and beauty salons. Since these businesses usually stay within their own ethnic community and network, they have limited opportunities to grow.

Disadvantage theory, based on Weber's (1930) views on how discrimination excludes certain groups from the mainstream labor markets, explains some of the strongest reasons why minorities start entrepreneurial activities (Smith-Hunter, 2003). Minorities excluded from labor markets prefer self-employment as an alternative to unemployment and underemployment. Entrepreneurship gives them a new source of income and survival (Smith-Hunter, 2003). Disadvantage theory is also used to explain immigrant entrepreneurship in cases where language and cultural barriers prevent them from finding jobs and earning income to support their families. Disadvantage theory explains that discrimination from mainstream markets due to race, ethnicity, religion, gender or race (Light, 1979; SmithHunter, 2003) holds some groups back. Remaining embedded in their own small network also prevents this category of MOBs from success and growth.

In both niche entrepreneurship and entrepreneurship resulting from discrimination, minority entrepreneurs start their businesses out of necessity rather than passion. While they face many barriers in starting their own businesses, it is usually their best chance to earn an income and survive. Regardless of why they start their own businesses, most face five big challenges: disadvantages in education and training, lack of personal qualifications, lack of access to resources, 
poor business knowledge and acumen, and sociocultural challenges.

\section{Disadvantages in education and training}

Today, most profitable enterprises are in the knowledge and high-tech economy requiring advanced knowledge and education. Minorities are poorly represented in these fields. Many don't have the opportunities to achieve literacy or advanced education needed to participate in lucrative value chains (Greenhalgh \& Lowry, 2011). Besides formal education, other kinds of communities -- such as Jewish entrepreneurs in New York's Garment District - have taught technical and entrepreneurial skills and competencies to their younger generations through apprenticeship practices and by providing role models, coaching and mentorship. However, communities like African Americans and Mexicans have long worked as agricultural workers or factory workers and have never been exposed to these entrepreneurial environments (Greenhalgh \& Lowry, 2011) and informal training opportunities. In the specific case of immigrant minorities, language barriers and devaluation of credentials earned in their own homeland make it very difficult for minorities to find jobs and get employed (Heilman \& Chen, 2003) and access entrepreneurial opportunities.

\section{Lack of personal qualifications}

The lack of appropriate educational credentials (Greenhalgh \& Lowry, 2011) holds some minorities back in acquiring the personal skills and abilities, expertise and appropriate competencies they need to run their own business. (Light \& Rosenstein, 1995; Bates, 2011; Didia, 2008). They also frequently lack experience working for others, which builds competencies that they use in their own businesses.

\section{Access to resources}

Minorities lack access to many resources, including the most important one: capital and financial resources. They mainly suffer from discrimination in lending policies and don't have the credit history necessary to borrow money (Bates, 1997; Dayanim, 2011). Minorities have a difficult time penetrating mainstream business networks and find themselves left out of the loop about upcoming bids and deadlines (Bates, 2001; Dayanim, 2011), resulting in lack of access to critical information and business networks. Usually due to their poor credit history, minorities also can't obtain bonding against breach of contract when strict bonding requirements are enforced (Dayanim, 2011), leading to inadequate capital and resources to complete a job.

\section{Poor business knowledge and acumen}

MOBs often have shortcomings in strategic clarity, employing and empowering talented human resources, managing cash, customer orientation and suffer from inadequate control systems, ineffective or inefficient processes and dysfunctional organizational structures (Greenhalgh \&Lowry,2011). These drawbacks hamper their business success. Lack of business acumen also causes problems in exploiting market opportunities, accessing new markets and acquiring a sufficient number of clients and contracts. This keeps MOBs small and limits their growth. Cross-sectional data shows that MOBs concentrate in several marginal lines of personal services and retailing -- including barber shops, small restaurants, mom-and- pop retail stores (Bates, 2011) and ethnic services and stores.

\section{Socio-cultural challenges}

Minority businesses are also hurt by ethnic stereotyping They are hindered by socioeconomic stratification (Heilman \& Chen, 2003) and negative views regarding minorities, especially about their ability to complete a job (Dayanim, 2011). Stereotypes about specific racial, ethnic or religious communities also nourish prejudicial social assumptions and images resulting in discriminatory treatment upon these groups (Godwyn \& Stoddard, 2011, p. 68). Discrimination also confines MOBs to low-income inner city locations creating location disadvantages (Didia, 2008).

All of the above mentioned challenges create barriers that limit access to financial capital and markets for MBOs and resulting in unequal opportunities for entrepreneurship. MOBs are generally smaller, less profitable and generally less viable firms than those owned by non-minorities as a consequence of these unequal opportunities. These barriers even discourage the minorities from even starting their own businesses (Bates et al., 2007).

\section{Supporting Minority Entrepreneurs}

Providing business support for minority entrepreneurs is an issue of special interest for researchers, policy makers, federal and local authorities, non-governmental organizations, universities and practitioners. Motivated by efforts to create social inclusion and combat exclusion, these parties attempt to develop policies targeting specific groups (Högberg, Ram \& Jones, 2014). Although not at the desired level and fulfilling the 
expectations yet, very promising efforts and attempts have been developed to support the movement of minority entrepreneurship, especially over the last decade. Below some of these efforts are discussed with some successful examples.

\section{Governmental support}

In 1953, the US was the first country to adopt entrepreneurial support aimed specifically at ethnic minorities through the Small Business Act (Högberg et al., 2014, p. 242). An example of a support mechanism is through "reserving a proportion of government contracts for MOBs" (Chatterji, Chay, \& Fairlie, 2014, p. 507). A company legally classified as a "Small Disadvantaged Businesses" (SDB) status is eligible for bidding and contracting in programs involving federal procurement. The Small Business Act defines economically disadvantaged individuals as "those socially disadvantaged individuals whose ability to compete in the free enterprise system has been impaired due to diminished capital and credit opportunities as compared to others in the same business area who are not socially disadvantaged" (Snyder, Kidalov \& Rendon, 2013, p. 402).

"To qualify as an SDB, a firm must, among other requirements, be majority owned by one or more socially and economically disadvantaged citizens. Socially disadvantaged individuals are those who have been subjected to racial or ethnic prejudice or cultural bias because of their identity as a member of a group without regard to their individual qualities. Business owners from five groups -- Black Americans, Hispanic Americans, Native Americans, Asian Pacific Americans, and Subcontinent Asia Americans-comprising 37 subgroups are presumed to be socially disadvantaged; non-minorities must demonstrate social disadvantage"(Snyder et al., 2013, pp. 401-402; Code of Federal Regulations [CFR] 2012a; 2012b; United States Code [USC] 2012).

The Minority Business Development Agency (MBDA) (https://www.mbda.gov/) is an agency of the US Department of Commerce promoting the growth of minority-owned businesses through its public and private sector programs, policy and research. MBDA links minority-owned businesses with capital, contracts and markets where they need to grow. They advocate for minority-owned businesses with elected officials, policy makers, and business leaders. The organization has a large spectrum of programs and resources to support minority entrepreneurs such as Business Centers, Grant Competitions, Inclusive Innovation Initiative, training programs and consultation services.

\section{Incubators and accelerators}

Incubators and accelerators provide resources and opportunities to build capacity for minority entrepreneurs. Business incubators and accelerators are organizations to increase the chance of survival for new start-ups. Such organizations "nurture young firms, helping them to survive and grow during the start-up period when they are most vulnerable" (Aernoudt, 2004, 127). These entities provide space, networking opportunities, seed funding and professional consulting. They also supply resources, R\&D assistance and risk capital through a network of external providers.

Reaching scarce resources through networks, enhancing network ability and building a network capacity are critical for entrepreneurs. Incubators and accelerators connect client entrepreneurs to resources and expertise via social networks. Entrepreneurs not only benefit from these connections but also learn the necessary political skills for networking efficiently, with incubators and accelerators serving as intermediaries (Ogutveren-Gonul \& Senyuva, 2016).

Scillitoe and Chakrabarti (2010) argue that business assistance is one of the major contributions of incubators/accelerators to new entrepreneurs. Business assistance provides support in all business-related areas such as business planning, tax assistance, personnel recruiting, marketing, management, accounting, legal expertise, accessing financial capital and business contracts. The incubators/accelerators also provide the opportunity for personal growth by administering workshops, seminars, personal mentoring and training to the entrepreneurs, equipping them with the necessary skills, competencies and entrepreneurial mindsets to become successful business owners (Ogutveren-Gonul \& Senyuva, 2016).

Number of incubators and accelerators supporting minority entrepreneurship has increased recently. Some examples include The Enterprise Center, Black Founders and NewMe (http://www.theenterprisecenter.com/, http://blackfounders.com/). Even though some of these organizations are very successful in fulfilling their mission, many others struggle to provide services to their resident start-ups. Those located in the heart of 
resources and innovation -- such as Silicon Valley, Chicago or New York City -- have better chances of supporting minority entrepreneurs.

\section{Non-profit community organizations}

A chamber of commerce is a local organization with the mission to support the local business owners' interests through building strong business networks. Chambers of commerce for specific minority populations, offering many programs for their communities, are among the most common support organizations for minority entrepreneurs. US Black Chambers, Inc. (http://usblackchambers.org/) is an association of over 100 self-sustaining, viable Black chambers and small business associations nationwide. They advocate for African American entrepreneurs and offer services in accessing capital, contracting, training and chamber development. Some of the regional African American chambers focus on supporting their members and existing businesses while others offer programs and services on a smaller and local scale to increase the number of minority businesses. For example, African American Chamber of Commerce Wisconsin (http://www.aaccwisconsin.org/revolving-loan-fund.html) offers the Revolving Loan Fund Program in collaboration with many banks and corporations and aims to increase access to capital for existing and new minority businesses, while developing partnerships with the business community.

United States Hispanic Chamber of Commerce (USHCC) has more than 200 local chambers, which advocate on behalf of more than 4.37 million Hispanicowned businesses (https://ushcc.com/). Likewise, some of the local chambers deliver their own programs directed at the specific needs of their own communities. Greater Philadelphia Hispanic Chamber of Commerce (http://www.philahispanicchamber.org) hosts conferences seeking to close the outcomes gap Latinos face in different industries, focusing on diversity and inclusion in human resources and best business practices. They established the Small Business Development and Education program addressing the needs of the Latino business owners and presenting its members with new business opportunities.

Asian chambers of commerce work in a similar fashion to promote entrepreneurship and business. For example, Virginia Asian Chamber of Commerce, with seven Mid-Atlantic locations across Virginia, partners with more than 30 prominent and powerful organizations such as The White House's Asian Pacific American Initiative, Minority Business Development Agency, Asian Chamber of Commerce and Entrepreneurship Development, Federal Reserve Bank, Procurement Technical Assistance Centers, US Small Business Administration and US Department of Commerce. Through its partnerships, the chamber offers programs, technical assisting, counseling and special events for member businesses, entrepreneurs, start-ups and small/medium sized companies. In recent years, Virginia Asian Chamber of Commerce helped more than 1,650 Asian entrepreneurs with one-to-one technical assistance sessions, industry councils, matchmaking events, business forums and summits, networking receptions and business education seminars/workshops.

Minority Chamber of Commerce in Miami Dade area, an umbrella organization embracing more than 1400 local members, established "The Start-up Program" to create wealth in minority disadvantage communities through entrepreneurship. The program offers "Business and Entrepreneurial Skills Training which delivers professional instruction designed to assist minority small business owners in managing their businesses more effectively and expand their opportunities for governments and private sector." They also offer advanced training for more established minority companies.

\section{Social capital and community network support}

In some rare cases, social capital and community support is used as a powerful tool to overcome the challenges for minority entrepreneurs. Social capital partly explains why Asian minorities in the US are relatively more successful than other minority groups (Fairlie \& Robb, 2010). It is a popular method for Chinese and Korean entrepreneurs to use rotating credit associations (RCAs), also called rotating savings and credit associations (ROSCA), to accumulate financial resources (Bates, 1997b; Calomiris \& Rajaraman, 1998; Volery, 2007). RCAs "are voluntary groupings of individuals who agree to contribute financially at uniformly-spaced dates towards the creation of a fund, which will then be allotted in accordance with some prearranged principle to each member of the group in turn" (Calomiris \& Rajaraman, 1998, p. 208). A common pool is created for funding the members of the group. RCAs typically arise when discrimination exerts strong influence over financial institutions resulting in the failure 
of these institutions to meet the needs of the minority entrepreneurs (Volery, 2007). Members of the RCAs share a common identity and provide social support for their in-group members, hence using the social capital and networks of their own community. "Social capital, in this case, comes from the trust that each participant has in the continuing contribution of others, even after they receive the pooled funds" (Portes, 1998, p. 13).

Asian minorities have been more successful in starting and running their businesses. Asian-owned businesses are 16.9 percent less likely to close, 20.6 percent more likely to have profits of at least $\$ 10,000$, and 27.2 percent more likely to hire employees than businesses owned by other minorities and their white counterparts (Fairlie and Robb, 2010, p. 145). Light indicates that "the logic of Asian-American business development raises questions about the absence of parallel development among American Blacks" (1972, p. 6). Similarly, Aldridge and Waldinger discuss the reasons of the underdevelopment of black businesses and point out "the fragmented social structure of black communities, which inhibits resource mobilization," as one of the primary reasons (1990, p. 62). Social capital is the good will created through social relations that can be mobilized to facilitate the attainment of needed resources (Adler \& Kwon, 2002) and lack of social capital and strong networks creates a disadvantage for the minority communities.

\section{Universities, colleges and foundations}

Colleges and universities are the most natural environments to support the young generation of entrepreneurs, and entrepreneurship programs have been in demand recently. Many new entrepreneurship programs and incubators have arisen as a result, and some of them have made a special effort to nurture minority entrepreneurs.

Ferris State University started the Latino Business and Economic Development Center to provide leadership and community entrepreneurship development for Latin entrepreneurs interested in contributing to the overall economic development of Latino communities of West Michigan. MN Mup (https://carlsonschool.umn.edu/mn-

cup/about/impact/minority-entrepreneur-initiative) in University of Minnesota, the largest statewide startup competition, has a minority entrepreneur initiative to acknowledge and address the specific challenges and opportunities that minority entrepreneurs face when trying to access capital, networks and market opportunities. University of Birmingham founded The Enterprise and Diversity Alliance, which is an innovative network dedicated to promoting minority entrepreneurship, located in the Center for Research in Ethnic Minority Entrepreneurship at Birmingham Business School. The center addresses the challenges faced by minority entrepreneurs, and through collaboration with large corporations and organizations, offers alternative solutions in three key areas: access to finance, access to critical networks leadership and management.

Historically Black Colleges and Universities (HBCU) were "created under the laws of segregation and, prior to 1964 , with the express purpose of educating African Americans" (Gasman, 2008). Today, there are 101 HBCUs (https://nces.ed.gov/ipeds/) in the US and they serve students of all races, even though the majority of their student population is African American students. The Historically Black Colleges and Universities Innovation and Entrepreneurship Collaborative (HBCU Collaborative) was announced in January 2014 - a joint initiative involving the Association of Public and Landgrant Universities (APLU) Office for Access and Success, APLU's Commission on Innovation, Competitiveness, and Economic Prosperity (CICEP), VentureWell, the United States Patent and Trademark Office and the United Negro College Fund (UNCF). The Lemelson Foundation and the Lumina Foundation have funded this initiative. "The HBCU Collaborative is a cohort of 15 public and private HBCUs that are committed to participating in a multi-year collaboration that will foster innovation, commercialization and entrepreneurship on their respective campuses to improve student success by implementing new institutional courses, transforming faculty pedagogy and creating partnerships with government and private industries." The HBCU Collaborative is a promising effort to increase innovation among African American students through a collaboration of multiple universities, companies, public and private institutions and foundations.

Many foundations also support the growth of minority entrepreneurship. Kauffman is probably the best known foundation specializing in entrepreneurship programs. In 2016, Kauffman granted $\$ 4.3$ million to organizations that support women and minority entrepreneurship. The foundation also gives grants to scholarly research enhancing minority entrepreneurship. Case 
Foundation's Inclusive Entrepreneurship Movement (https://casefoundation.org/program/inclusiveentrepreneurship (https://casefoundation.org/program/inclusiveentrepreneurship/) /)aims at democratizing entrepreneurship through reducing barriers faced by diverse entrepreneurs and intentionally leveraging a more diverse group of innovators and entrepreneurs through piloting programs serving entrepreneurs of color. They focus on increasing social capital, financial capital and inspirational capital for minority entrepreneurs. Techstars Foundation (http://diversity.techstars.com/foundation) describes itself as an organization committed to having metaimpact on increasing diversity in tech startup world through global and regional initiatives by breaking down barriers. Many other foundations, including the Lemelson Foundation and Lumina Foundation, provide resources for minority entrepreneurs at different scales and sometimes through indirect efforts.

\section{Recommendations}

Various sectors of the society have made promising efforts to support minority entrepreneurship. These include public and private institutions such as universities, incubators, accelerators, investors and researcher scholars. The major problem at this point seems to be expanding these efforts to larger audiences. For example, the HBCU Collaborative represents 15 of the $101 \mathrm{HBCUs}$, or just $15 \%$ of the total number of historically black colleges and universities. Most of the existing cooperative projects between universities and non-university organizations such as incubators, accelerators, companies and foundations are based on short-term collaborations: joint pitch competitions and limited training opportunities in the form of workshops. Building longer-term relationships such as the HBCU Collaborative would be more effective in supporting new minority entrepreneurs.

Similarly, while the number of incubators and accelerators focused on minority entrepreneurs has increased, many more are needed, especially near highly unemployed or underemployed minority populations. Most of the existing incubators and accelerators focus on African American population but neglecting other minority groups. Minority incubators provide space, networking and administrative services to their residents and help the entrepreneurs develop business knowledge and skills. However, more resources are needed to help them develop an entrepreneurial mindset, which will be critical in helping them be more self-sufficient after they leave the incubator and strike out on their own.

To empower minority entrepreneurs economically, we must promote and support them in a more planned, systematic, strategic and persistent manner. Below are some suggestions for individuals and public and private institutions whose joint support and collaboration is needed for successful planning and implementation of support mechanisms:

\section{Building social capital}

Communities need to build trust and strong ties to increase their social capital. Minority communities need to develop ways to leverage social capital through building new social networks and gaining access to the existing ones. Chambers of commerce of each unique community should connect with one another and build a macro network to share information and best practices and help their members access different social and business networks and share resources.

\section{Providing role models and mentoring}

Local incubators/accelerators and universities should invite successful minority entrepreneurs into their programs to provide role models for potential minority entrepreneurs. Individuals need to see examples of success from others who share their identity and culture. Successful entrepreneurs can mentor the new ones and provide internship opportunities, leading to a long-term relationship between the two parties benefiting them both and mobilizing human capital.

\section{Efforts to increase credibility}

Building new and alternative credit score models would help increase the minority entrepreneurs' access to a wider range of financial resources. Building credit history through micro loans, loans received through partnerships and impact investing could open new doors to start and scale up minority businesses. Government, investment companies, financial institutions and universities share a common responsibility to develop new policies around this issue.

\section{Increasing awareness}

One of the problems minority entrepreneurs face is the limited access to critical information. Minorities, especially immigrant entrepreneurs with limited language proficiency, stay within a closed community and are not aware of the support mechanisms in their 
regions. They most likely do not even hear about programs, competitions, grants and activities developed to help them start their own businesses. As discussed in the previous section, many organizations offer specialized and targeted programs to meet the needs of minority entrepreneurs. Local governments, chambers of commerce and universities should take joint action to educate and inform their local communities about the existing opportunities. They should create better platforms to share knowledge and engage larger populations of minority entrepreneurs into these programs.

1 First section of this paper (State of Minority Entrepreneurship in the U.S.) has been prepared as part of a proposal to apply for the Kauffman-Emory Seed Grants Program to Stimulate Research on Early-Stage Entrepreneurship, 2017, in collaboration with The Enterprise Center, Philadelphia.

\section{References}

Adkins, C. L., \& Samaras, S. A. (2013). The challenges of business ownership: A comparison of minority and non-minority women business owners. Journal of Applied Management and Entrepreneurship, 18(3), 72-93.

Adler, P. S., \& Kwon, S. W. (2002). Social capital: Prospects for a new concept. Academy of management review, 27(1), 17-40.

Aldrich, H. and Waldinger, R. (1990). Trends in ethnic businesses in the United States. In R.Waldinger, $\mathrm{H}$. Aldrich, and R. Ward, eds., Ethnic Entrepreneurs: Immigrant Business in Industrial Societies. Newbury Park, CA: Sage.

Aernoudt, R. (2004). Incubators: Tool for entrepreneurship? Small Business Economics, 23(2), 127-135.

Badal, S. (2014). Why so many new companies fail during their first five years. Gallup Business Journal, 8

Barr, M.S. (2015). Minority and Women Entrepreneurs: Building Capital, Networks, and Skills. The Hamilton Project.

Bates, T. (1997). Unequal Access: Financial Institution Lending to Black-and White-Owned Small Business Start-ups. Journal of Urban Affairs, 19(4), 487-495.
Bates, T. (1997b). Financing small business creation: The case of Chinese and Korean immigrant entrepreneurs. Journal of business venturing, 12(2), 109-124.

Bates, T., Jackson III, W. E., \& Johnson Jr, J. H. (2007). Advancing research on minority entrepreneurship. The Annals of the American Academy of Political and Social Science, 613(1), 10-17.

Bates, T. (2001). Minority business access to mainstream markets. Journal of Urban Affairs, 23(1), 41-56.

Bates, T. (2011). Minority Entrepreneurship. Foundations and Trends ${ }^{\circledR}$ in Entrepreneurship, Vol. 7: No. 3-4, pp 151-311. http://dx.doi.org/10.1561/0300000036

(https://www.nowpublishers.com/article/Details/ENT-03 6)

Boyd, R. L. (1996). The great migration to the north and the rise of ethnic niches for African American women in beauty culture and Hairdressing, 1910-1920. Sociological Focus, 29(1), 33-45.

Calomiris, C. W., \& Rajaraman, I. (1998). The role of ROSCAs: lumpy durables or event insurance? Journal of development economics, 56(1), 207-216.

Chatterji,A.K., Chay, K.Y. \& Fairlie, R.W. (2014). The impact of city contracting set-asides on black selfemployment and employment. Journal of Labor Economics, 2(3): 507-561.

Code of Federal Regulations (CFR). (2012a). Business Development/Small Disadvantaged Business Status Determinations. Title 13, Part 124. Washington, DC: U.S. Government Printing Office.

Code of Federal Regulations (CFR). (2012b). Determination of Group Eligibility for MBDA Assistance. Title 13, Part 1400. Washington, DC: U.S. Government Printing Office.

Dayanim, S. L. (2011). Do Minority-Owned Businesses Face a Spatial Barrier? Measuring Neighborhood-Level Economic Activity Differences in Philadelphia. Growth and Change, 42(3), 397-419.

Didia, D. (2008). Growth without Growth: An Analysis of the State of Minority Owned Businesses in the United 
States. Journal of Small Business and Entrepreneurship, 21(2): 195-214.

Fairlie, R. W., \& Robb, A. M. (2008). Race and entrepreneurial success: Black-, Asian-, and Whiteowned businesses in the United States . Cambridge, MA: MIT Press Books.

Gasman, M. (2008). Historically Black colleges and universities. John Wiley \& Sons, Ltd.

Godwyn, M., \& Stoddard, D. (2017). Minority women entrepreneurs: How outsider status can lead to better business practices. California: Stanford University Press.

Greenhalgh, L., \& Lowry, J. H. (2011). Minority business success: Refocusing on the American Dream California: Stanford University Press.

Heilman, M. E., \& Chen, J. J. (2003). Entrepreneurship as a solution: the allure of self-employment for women and minorities. Human Resource Management Review, 13(2), 347-364.

Högberg, L., Ram, T.S. \& Jones, T. (2014). Categorizing and labeling entrepreneurs: Business support organizations constructing the other through prefixes of ethnicity and immigrantship. International Small Business Journal, 34(3): 242-260.

Light, I. 1972. Ethnic enterprise in America. Berkeley: University of California Press.

Light, I. (1979). Disadvantaged minorities in selfemployment. International Journal of Comparative Sociology, 20, 31.

Light, I. \& Rosenstein, C. (1995). Race, Ethnicity and Entrepreneurship in Urban America.New York: Aldine De Gruyter.

Ogbolu, M. (2015). Legitimacy, Attitudes, and Intended Patronage: Understanding Challenges Facing Black Entrepreneurs. Journal of Developmental Entrepreneurship, 20(01):1550007 (1-19).

Ogutveren-Gonul, O. \& Senyuva, Z. (2016). "The Role of Business Incubators on Start-Up Growth". Paper presented at The Society for Global Business \& Economic Development Conference, Montclair, NJ.
Portes, A. (1998). Social capital: Its origins and applications in modern sociology. Annual review of sociology, 24(1), 1-24.

Scillitoe, J. L., \& Chakrabarti, A. K. (2010). The role of incubator interactions in assisting new ventures. Technovation, 30(3), 155-167.

Smith-Hunter, A. (2003). Diversity and entrepreneurship: Analyzing successful women entrepreneurs. Univ Pr of Amer.

Sonfield, M. C. (2001). Re-defining "minority business": Challenges and opportunities. Journal of Developmental Entrepreneurship, 6(3), 269-276.

Snyder, K., Kidalov, M. \& Rendon, R.G. (2013). Diversity governance by convenience? Federal contracting for minority-owned businesses. Public Administration Quarterly, 37: 393-432.

United States Code (USC). (2012). The Small Business Act. Title 15, Chapter 14A: 631-657q. [Originally enacted as The Small Business Act of 1953, Pub. L. No. 83-163, 67 Stat. 232]. Washington, DC: U.S. Government Printing Office.

Volery, T. (2007). Ethnic entrepreneurship: a theoretical framework. Handbook of research on ethnic minority entrepreneurship, 1, 30-41.

Weber, M. (1930). The Protestant Ethic and the Spirit of Capitalism. London and New York: Routledge 